\title{
An Exploratory Study of Personal Financial Wellbeing Determinants: Examining the Moderating Effect of Gender
}

\author{
Leila Falahati ${ }^{1} \&$ Mohamad Fazli Sabri ${ }^{2}$ \\ ${ }^{1}$ Department of Women Studies, Institute of Social and Cultural Studies, Ministry of Science, Research and \\ Technology, Tehran, Iran \\ ${ }^{2}$ Department of Resource Management and Consumer Studies, Faculty of Human Ecology, Universiti Putra \\ Malaysia, Malaysia \\ Correspondence: Leila Falahati, Department of Women Studies, Institute of Social and Cultural Studies, Ministry \\ of Science, Research and Technology, Tehran, Iran. E-mail: Falahati@ISCS.ac.ir
}

Received: August 2, 2014 Accepted: December 5, 2014 Online Published: January 14, 2015

doi:10.5539/ass.v11n4p33 URL: http://dx.doi.org/10.5539/ass.v11n4p33

\begin{abstract}
Financial educators have placed importance on the study of the determinants of financial wellbeing for some decades now. The subject of the research has comprised factors such as marital status, employment status, education, income and health, which impact on financial wellbeing. However, there is as yet, a lack of research on the perceived influence of differences in financial wellbeing between the genders, particularly within the Asian context. The present research evaluates the moderating effect of gender on the determinants of financial wellbeing among college students in Malaysia. Samples for this study comprised students in Malaysian universities. The multi stage stratified random sampling technique was utilized to select the respondents, while self-administered questionnaires were used to collect the data. Further, a multi-group analysis approach using AMOS was used in studying the influence of gender on financial wellbeing. The findings of the present research show that among college students, gender has a substantial moderating effect on the factors related to financial wellbeing.
\end{abstract}

Keywords: gender differences, financial wellbeing, financial management, financial strain, consumer socialization, financial knowledge, socialization agents influence, money attitude

\section{Introduction}

The rapid development in Malaysia has created more opportunities in education, employment and an overall improved welfare of Malaysians. Thus, the improved economic situation has provided Malaysians with more opportunities to earn higher incomes and raise their standard of living through conducting business or employment. In addition, the increase in the number of higher educational institutions in Malaysia has led to the enrolment of a higher number of students ( $\mathrm{Da}, 2007)$. Further, in 2009, the number of females enrolled in Malaysian institutions of higher education rose to $76 \%$ of total students (MOHE statistics, 2009). The Figureure for 2013 remained high at $65 \%$, exceeding the number of males enrolled in Malaysian institutions of higher learning. The estimates are that with the growing number of women in higher education, the participation of women in the labour force has increased consequently, resulting in the enhancement of the economic position of women and gender equality (Bhatti, Shar, Shaikh, \& Nazar, 2010).

While the increased participation of women in higher education brings with it the promise of better economic welfare, the issue of women's ability in money management and financial behvaiour remains a concern due to women's low level of financial literacy (Lusardi \& Mitchell, 2011; Mottola, 2013), their lower financial management skills (Hung, Yoong, \& Brown, 2012) and their negative attitude toward money (Borden, Lee, Serido, \& Collins, 2008). These gender differences in principal financial skills may result in differences in financial behaviour between the two genders and in differences in money management and levels of financial wellbeing between male and female college students. Prior research on college students have revealed important differences between women and men in financial matters. These differences are women are more likely to have a higher number of credit cards than males (Armstrong \& Craven, 1993; Hayhoe, Leach, \& Turner, 1999); and women report a higher risk of debt payment (Armstrong \& Craven, 1993), later financial socialization and a lower level of financial literacy (Falahati \& Paim, 2011). As such, women and men experience different levels of 
financial wellbeing due to different perceived levels of experiences in financial skills and financial literacy, especially during the socialization process.

Several studies have been conducted to assess the financial management of college students in the US and the UK; however, similar studies in the Asian context are still rare. A limited number of studies have been conducted to study the financial management of Malaysian college students. These studies include Kamaruddin and Mokhlis (2003); Masud, Rahim, Paim, and Britt (2004); and Sabri, MacDonald, Hira, and Masud (2010). A study by Bakar, Masud and Jusoh (2006) on financial management among Malaysian college students showed students know that they can obtain loans from the National Higher Education Fund Corporation (PTPTN) but have a negative attitude toward loan repayment. Students are also dependent on loans provided by PTPTN and believe that these loans are an important factor that will affect their life after graduation. Therefore, students' level of financial skills and attitude play an important role in determining their future success or failure. Further, Fazli and Falahati (2012) studied subjective financial wellbeing among Malaysian college students and found that financial literacy has the greatest effect on the financial management of Malaysian college students, which in turn enhances their perceived level of financial wellbeing. In addition, another study in the Malaysian context indicated that religion plays an important role in students' financial management. Compared to students of other religions, Muslim students follow family advice regarding financial matters and therefore perceive a lower level of financial strain (2014). However, while previous studies have examined the effect of different factors on financial matters in the Malaysian context, the study of differences in financial wellbeing between the genders is scarce. Accordingly, understanding the differences between female and male students with regard to their financial wellbeing should be one of the focuses of educators. This understanding can be used to build a standard educational programme to equip the young generation with the necessary knowledge and skills to perform well in the workplace and in life. Therefore, the focus of this study was to determine the moderating effect of gender on the relationship of financial wellbeing predictors among Malaysian college students.

\section{Literature Review}

The 21st century began with much concern among financial educators regarding issues related to personal and family monetary practices (Braunstein \& Welch, 2002, November). The expansion of money and financial services has resulted in easier access to money, which in turn has increased the experience of financial debt among people, especially young adults. Assessment of research findings have revealed that young adults, especially college students fail to manage their expenditure and therefore fall into financial strain. Previous studies related to students' financial management have shown that upon entering university, students have more access to credit cards and therefore experience high level of stress due to high debt, and most have financial problems and perceive low level of satisfaction with their financial situation (Holub, 2002; NellieMae, 2002; Norvilitis et al., 2006; Norvilitis, Szablicki, \& Wilson, 2003). However, these problems may be rooted in a low level of financial knowledge and the high effect of friends and media on students' financial behaviour and negative attitude toward money (Norvilitis \& Santa Maria, 2002; Roberts \& Jones, 2001). Findings of research on college students in the US have indicated that financial stress and financial problems are the main reasons for students dropping out of college (Duck9Report, 2007). Chen and Volpe (1998) conducted a study of financial practices among college students and their findings indicate that financial knowledge has positive and significant effect on students' financial management. Researchers in the field of financial education (Hilgert \& Hogarth, 2003; Norvilitis et al., 2006; Perry \& Morris, 2005) reviewed previous findings and concluded that financial literacy is one of the most important determinants of financial management among college students.

While a wide range of studies indicate the effect of financial knowledge as the main determinant of financial management, other studies (Allen, Edwards, Hayhoe, \& Leach, 2007; Hayhoe, Leach, Turner, Bruin, \& Lawrence, 2000) indicate the role of financial attitude as a prior factor in financial practices. Research findings also indicate that financial attitude is dependent on several causes such as socialization process and socio-demographic factors such as age and gender. For example, (Hira \& Mugenda, 2000; Lim, Teo, \& Loo, 2003) have indicated that males and females comprehend money differently due to differences in consumer socialization during childhood. Gender differences in financial management and financial wellbeing is a matter of interest among educators of family economics. Assessment of statistics in financial matters indicate that males and females have different levels of financial knowledge, money attitude and financial management, with females having lower levels in all items, and therefor they perceive different levels of financial wellbeing as well. Previous studies confirm the assumption that differences in the socialization process (Gutter, Garrison, \& Copur, 2010; NewComb \& Rabow, 1999; Shim, Xiao, Barber, \& Lyons, 2009) result in differences in financial matters and therefore women are more dependent on men in financial decisions. For example, the findings of Newcomb and Rabow (1999) confirm that through the socialization process, boys and girls receive different financial 
messages from parents, and interestingly, while boys participate in most family financial decisions, girls are excluded from financial debates and discussions.

Therefore, girls in most cultures have been socialized with lower information regarding money, and consequently in their life cycle, they perceive a higher level of problems regarding money matters, especially during their advanced years. However, findings of some studies (Goldscheider, 1990; Keith, 1993; Yin-Fah, Masud, Hamid, \& Paim, 2010), indicate that women perceive a lower level of financial wellbeing as they age since most of them have been uninformed about financial issues such as investment and insurance and are dependent on their husbands. On other hand, males perceive a higher level of financial strain due to the higher effect of their friends and the findings also indicate males are more involved in risky behaviours such as smoking, debt and even gambling (Hayhoe et al., 2000; Owens, Lacey, Rawls, \& Holbert-Quince, 2010). Therefore, understanding the factors that explain financial wellbeing among males and females is important in part to extend policies to enhance the financial situation both of males and females by improving their knowledge, positive attitude and efficient management. In addition, exploring the effect of gender on financial issues among youth could provide a valid basis for expanding parents' information regarding the importance of consumer socialization and also financial educators who seek to encourage, teach, and support youth with important and inevitable financial choices before entering the job market. Further, the present study initiated a model of predicting financial wellbeing and the main objective was to assess whether gender has effect on the factors that predict financial wellbeing among college students. As stated earlier, several factors affect financial wellbeing and therefore the main hypotheses are stated as follows: (1) there are gender differences between male and female students in the relationship between money attitude, consumer socialization process, primary and secondary socialization agents, and financial wellbeing; (2) there are gender differences in the effect of financial management and financial strain on the financial wellbeing of male and female students.

\section{Methodology}

\subsection{Instrumentation}

\subsubsection{Financial Wellbeing}

To measure financial wellbeing, a 6-item scale was developed by adopting items from previous studies such as Hira and Mugenda (1999) and Lown and Ju (1992) measurements. Scale items were concerned with the following issues: "total savings", "financial management ability" "present economic situation", "capability to meet wants", "enough money for rainy days" and "capability to spend". Students were asked to subjectively assess themselves on a self-anchoring ladder (Cantril, 1965) ranging from 1 (dissatisfied) to 10 (strongly satisfied).

\subsubsection{Financial Knowledge}

To measure financial knowledge, a test involving 25 questions regarding financial records, savings, financial goals, retirement, investments, banking systems, time value of money, education loans, wills, insurance, and general knowledge on personal finance was provided. Since the measurement was a correct/wrong answer test, to enhance the fit of the model, this construct was entered into the model as an observed variable.

\subsubsection{Childhood Consumer Experiences}

This construct was measured by a scale that included 10 items which were adopted from previous studies on consumer socialization, such as Hira (1997). To enhance the validity, some of items were modified to suit the Malaysian context. To determine the age students began to practise financial management, a score answer was provided including "before 7 years old", "7-12 years old", "13-15 years old", "16-17 years old", "after 18 years old" and "Never". The childhood consumer experiences score was calculated by computation of the score of items from 1 to 6 for 10 statements. These never received the lowest score (1) and the earliest age (before 7 years old) obtained the maximum score (6). Six items were dropped in order to improve the construct fitness.

\subsubsection{Secondary and Primary Socialization Agents}

In order to measure secondary and primary socialization agents, several measurements were assessed. Reviewing the literature revealed that John (1999) and Hira (1997) considered this construct with a scale that included 11 items. Secondary socialization agents included agents such as magazines, mass media, advertisements, peer group, mobile phones and the Internet. Primary socialization agents included mother, father, siblings, school and religion. To measure the influence of every socialization agent, students were asked to rate the eleven items on an answer scale from 1 (no influence) to 10 (the most influence). The scores for secondary and primary socialization agents were calculated by adding up the scores of items from 1 to 10 for eleven statements. A maximum score for every agent indicates a greater level of influence of the particular socialization agent. Also, 
to improve the fitting of the construct, two items were dropped from the secondary socialization agents and one item was dropped from the primary socialization agents.

\subsubsection{Money Attitude}

Several measurements were developed to assess money attitude such as the Money Attitude Scale (MAS) of Yamauchi and Templer (1982), the Money Beliefs and Behaviors Scale of Furnham (1984), the Money Ethic Scale of Tang (1992). However since in present study it was important to measure money attitude comprehensively, therefore the Furnham measurement was selected and money attitude assessed by adopting 6 dimensions of Money Beliefs and Behavior Scale (MBBS) of Furnham and to enhance the validity some of items were modified to the context of Malaysia. MBBS scale (1996) contained 6 dimensions such as inadequacy/anxiety, obsession, security, retention, power/prestige and effort/ability. Moreover, the self-gratification dimension was changed with effort/ability dimension after the factor analysis. Six dimensions were measured with a 19-items scale on a 4-point Likert scale. Respondents may rate the agreement with each item on a respondent's scale from 1 (strongly agree) to 4 (strongly disagree). After fitting the model, the security dimension was dropped and only five dimensions were contributed to the model as money attitude dimensions. It may note that all 5 dimensions were negative; hence higher score for items revealed more negative attitude toward money among respondents.

\subsubsection{Financial Management}

Financial management in the present study contained two dimensions comprising savings and spending practices. Spending behaviour was measured by a Yes/No scale that included 11 items. Respondents had to indicate whether they spent money on items such as mobile phone, games (bowling, snooker), entertainment magazines, Internet café, beauty salon, movies, gambling and clubbing, drugs, cigarettes and alcohol. This construct was computed by adding up the selected items. Students who selected more items received a lower score that indicates a more risky spending behaviour and vice-versa.

In order to measure saving behaviour, a five-items scale was developed by adapting three items from Hilbert and Hogart (2003) and two items were added based on the Malaysian context. The saving behaviour construct included 5-items like frequency of saving in a six months' period, having savings account, saving for short term, saving for future, having enough money to meet financial needs while in university, and having enough money that can be put into savings. The savings behaviour was measured by computing the saving scores. The higher the score, the better the savings behaviour and the lowest score indicates risky saving practices. Finally, financial management was measured by summing up spending and savings practices, and a higher score indicates better financial management and a low score indicates poor financial management. However, to enhance the fitness of the model, financial management contributed to the model as an observed construct.

\subsubsection{Financial Strain}

In the present study, financial strain was assessed by using a 10-items scale used by the Financial Counseling Clinic at Iowa State University (2004) that included a list of financial problems. Some of the items were modified based on the Malaysian context. This was to enhance the validity of the measurement. Students rated the experience of each problem on a 5-point Likert scale ranging from Never (1) to Every day (5). However, financial strain was entered into the model as an observed variable.

\subsection{Sample Procedure and Sample Profile}

The study sample comprised 2,500 students from eleven universities in Malaysia in 2009. These included five private universities (Universiti Technologi Petronas, Universiti Tun Abdul Razak, Universiti Tunku Abdul Rahman, Universiti Tenaga Nasional, and Multimedia University) and six public universities (Universiti Putra Malaysia, Universiti Teknologi Malaysia, Universiti Teknologi MARA, Universiti Sains Malaysia, Universiti Malaysia Sabah, and Universiti Malaysia Sarawak). The six public and five private universities were selected randomly from a list of all Malaysian public and private universities. However, Universiti Putra Malaysia was specifically selected as it has a financial education programme.

350 students were randomly selected from each university from lists obtained from the student affairs office of the selected universities. A self-administered questionnaire was distributed to each student to collect the data. Out of the total of 3,850 questionnaires distributed, 2,519 were completed and usable, of which 2,500 contributed to the data analysis in the present study. To conduct structural equation modelling, the researcher selected randomly 700 respondents from the original data for the enhancement of the accuracy of the results. Bentler and Chou (1987) recommended that for meaningful and interpretable values for structural equation modelling (SEM), the ratio of 5-10 participants per estimated parameter rule be used to calculate the sample size. 
Therefore, based on this rule and considering a $65 \%$ respondent rate, a sample of 700 is suitable as the sample size. The sample mean age was 21 years while $43 \%$ of the respondents were male and $56 \%$ were female.

\section{Results and Discussion}

In order to construct the model, the fitness of each construct was first assessed, after which the overall model was tested. Results of the overall model $(\chi 2 / \mathrm{df}=3.191, \mathrm{p}<0.001, \mathrm{CFI}=.901 ; \mathrm{GFI}=.886$; RMSEA $=.56)$ revealed that the model might be improved. Therefore, to increase the fitness of the model, a number of items were dropped and the fitness of the adjusted model was improved and showed an adequate fit $(\chi 2 / \mathrm{df}=3.035, \mathrm{p}<$ $0.001, \mathrm{CFI}=.938 ; \mathrm{GFI}=.913 ; \mathrm{RMSEA}=.054)$. In addition, to test whether gender moderates the relationship between childhood consumer experiences, primary and secondary socialization agents, financial knowledge, financial management and financial strain on financial wellness, a multi-group approach was employed.

\subsection{Male Students}

Table 1. The results of path coefficients among male students

\begin{tabular}{llllll}
\hline Items & Estimate & S.E. & Std. Regression & C.R. & P \\
\hline Primary socialization agents $\rightarrow$ Financial Management & .404 & .125 & .208 & 3.231 & .000 \\
Secondary socialization agents $\rightarrow$ Financial Management & -.747 & .155 & -.289 & -4.831 & .000 \\
Financial knowledge $\rightarrow$ Financial Management & .126 & .024 & .262 & 5.156 & .000 \\
Secondary socialization agents $\rightarrow$ Financial Strain & 1.437 & .246 & .333 & 5.837 & .000 \\
Childhood consumer experience $\rightarrow$ Financial Strain & -.546 & .282 & -.102 & -2.934 & .040 \\
Financial Knowledge $\rightarrow$ Financial Strain & -.087 & .036 & -.108 & -2.434 & .015 \\
Financial Management $\rightarrow$ Financial Strain & -.636 & .084 & -.381 & -7.585 & .000 \\
Financial Knowledge $\rightarrow$ Financial Wellness & .053 & .014 & .193 & 3.871 & .000 \\
Secondary socialization agents $\rightarrow$ Financial Wellness & .176 & .085 & .119 & 2.075 & .030 \\
Money attitude $\rightarrow$ Financial Wellness & .159 & .068 & .143 & 2.358 & .018 \\
Financial Management $\rightarrow$ Financial Wellness & -.370 & .115 & -.193 & -3.208 & .001 \\
Financial strain $\rightarrow$ Financial Wellness & .186 & .035 & .325 & 5.298 & .000 \\
\hline
\end{tabular}

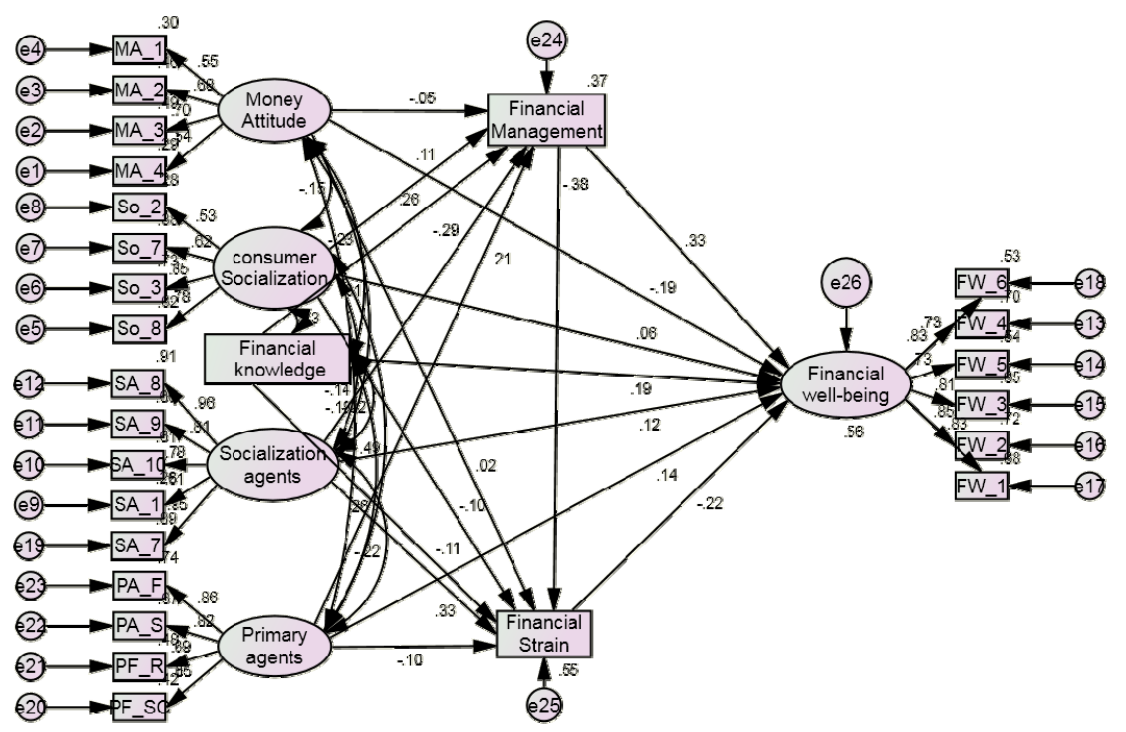

Figure 1. Predictors of financial wellbeing among male students

As shown in Table 1, the findings show that the financial wellbeing of male students is influenced by primary socialization agents $(\mathrm{b}=.143, \mathrm{CR}=2.35, \mathrm{P}<.05)$; secondary socialization agents $(\mathrm{b}=.119, \mathrm{CR}=2.07, \mathrm{P}<.05)$; financial knowledge $(\mathrm{b}=.193, \mathrm{CR}=3.871, \mathrm{P}<.05)$; money attitude $(\mathrm{b}=-.193, \mathrm{CR}=-3.208, \mathrm{P}<.05)$; financial 
management $(\mathrm{b}=.325, \mathrm{CR}=5.298, \mathrm{P}<.05)$; and financial strain $(\mathrm{b}=-.223, \mathrm{CR}=-3.379, \mathrm{P}<.05)$. The findings further reveal that among male students, the significant predictors of financial strain are childhood consumer experiences $(\mathrm{b}=-.102, \mathrm{CR}=-2.93, \mathrm{P}<.05)$; secondary socialization agents $(\mathrm{b}=.333, \mathrm{CR}=5.83, \mathrm{P}<.05)$; financial knowledge $(\mathrm{b}=-.108, \mathrm{CR}=-2.43, \mathrm{P}<.05)$; and financial management $(\mathrm{b}=-.381, \mathrm{CR}=-7.58, \mathrm{P}<.05)$. Lastly, the path coefficients indicate that financial knowledge $(\mathrm{b}=.262, \mathrm{CR}=5.156, \mathrm{P}<.05)$; primary socialization agents $(\mathrm{b}=.208, \mathrm{CR}=3.231, \mathrm{P}<.05)$; and secondary socialization agents $(\mathrm{b}=-.289, \mathrm{CR}=-4.831, \mathrm{P}<.05)$ are significant predictors of financial management for male students. Given together, the results show that male students with greater financial knowledge are more affected by secondary and primary socialization agents and those with greater financial management perceive a higher level of financial wellbeing. On the other hand, students with a higher level of financial strain and negative money attitude perceive a lower level of financial wellbeing. Assessment of predictors' beta coefficients reveals that financial management is the most powerful predictor of financial wellbeing among male students (Figure 1).

\subsection{Female Students}

With regard to female students, the results of path coefficients among female students (shown in Table 2) indicate that, together, childhood consumer experiences $(\mathrm{b}=.148, \mathrm{CR}=2.95, \mathrm{P}<.05)$; primary socialization agents $(\mathrm{b}=.13, \mathrm{CR}=2.79, \mathrm{P}<.05)$; secondary socialization agents $(\mathrm{b}=.135, \mathrm{CR}=2.44, \mathrm{P}<.05)$; financial knowledge $(\mathrm{b}=.327, \mathrm{CR}=8.13, \mathrm{P}<.05)$; financial management $(\mathrm{b}=.2, \mathrm{CR}=4.36, \mathrm{P}<.05)$; and financial strain $(\mathrm{b}=-.308, \mathrm{CR}=$ $-5.88, \mathrm{P}<.05)$ are significant predictors of financial wellbeing. The findings also reveal that secondary socialization agents $(\mathrm{b}=.438, \mathrm{CR}=7.53, \mathrm{P}<.05)$; primary socialization agents $(\mathrm{b}=-.116, \mathrm{CR}=-2.57, \mathrm{P}<.05)$; financial knowledge $(\mathrm{b}=-.097, \mathrm{CR}=-2.49, \mathrm{P}<.05)$; and financial management $(\mathrm{b}=-.271, \mathrm{CR}=-6.27, \mathrm{P}<.05)$ are significant predictors of financial strain. Lastly, the results of path coefficients indicate that financial knowledge $(\mathrm{b}=.175, \mathrm{CR}=3.76, \mathrm{P}<.05)$; money attitude $(\mathrm{b}=-.174, \mathrm{CR}=2.39, \mathrm{P}<.05)$; and childhood consumer experiences $(b=.29, \mathrm{CR}=5.01, \mathrm{P}<.05)$ are significant predictors of financial management among female students. These findings indicate that female students who have greater financial knowledge, who are more influenced by socialization agents, with earlier consumer socialization and greater financial management have a greater level of financial wellbeing. In addition, the results show that financial knowledge has the strongest effect on financial wellbeing among female students. However, unlike for the male students, money attitude does not contribute to predict financial wellbeing among female students (Figure 2).

Table 2. The results of path coefficients among female students

\begin{tabular}{llllll}
\hline Items & Estimate & S.E. & Std. Regression & C.R. & P \\
\hline Childhood consumer experience $\rightarrow$ Financial Management & .917 & .183 & .29 & 5.010 & .000 \\
Money attitude $\rightarrow$ Financial Management & -.703 & .302 & -.174 & -2.326 & .020 \\
Financial knowledge $\rightarrow$ Financial Management & .091 & .024 & .175 & 3.769 & .000 \\
Secondary socialization agents $\rightarrow$ Financial Strain & 1.618 & .215 & .438 & 7.534 & .000 \\
Primary socialization agents $\rightarrow$ Financial Strain & -.427 & .166 & -.116 & -2.570 & .010 \\
Financial Knowledge $\rightarrow$ Financial strain & -.082 & .033 & -.097 & -2.497 & .013 \\
Financial management $\rightarrow$ Financial strain & -.441 & .070 & -.271 & -6.274 & .000 \\
Financial Knowledge $\rightarrow$ Financial Wellness & .104 & .013 & .327 & 8.135 & .000 \\
Secondary socialization agents $\rightarrow$ Financial Wellness & .189 & .077 & .135 & 2.449 & .014 \\
Primary socialization agents $\rightarrow$ Financial Wellness & .181 & .065 & .13 & 2.796 & .005 \\
Childhood consumer experience $\rightarrow$ Financial Wellenss & .288 & .097 & .148 & 2.958 & .003 \\
Financial Management $\rightarrow$ Financial Wellness & .123 & .028 & .2 & 4.365 & .000 \\
Financial strain $\rightarrow$ Financial Wellness & -.117 & .020 & -.308 & -5.886 & .000 \\
\hline
\end{tabular}

\subsection{Moderating Effect of Gender}

In order to evaluate whether gender moderates the association of selected predictors with financial wellbeing, a multi-group examination was conducted. Hence the study sample was separated into two clusters, one comprising male students and the other female students. To achieve the moderation effect, the $Z$ score $(\leq \pm 1.96)$ on the assumed association was estimated and compared between two clusters (Male and Female). Results of comparisons of scores estimated for assumed relationships reveal following significant differences: 


\subsubsection{Predicting Financial Wellbeing}

Financial knowledge $(\mathrm{z}=2.739)$ is a greater predictor of financial wellbeing in the case of female students than in male students.

\subsubsection{Predicting Financial Strain}

Financial management $(z=14.49)$ is a greater predictor of financial strain for male students compared to female students.

\subsubsection{Predicting Financial Management}

Childhood consumer experiences $(z=2.04)$ contribute to predict financial management among female but not male students. Among male students, secondary socialization agents $(z=2.44)$ do contribute to predict financial management. However, these factors do not contribute to predict financial management among female students. Finally, financial knowledge $(\mathrm{z}=10.45)$ has a stronger effect on predicting financial management among male students than female students.

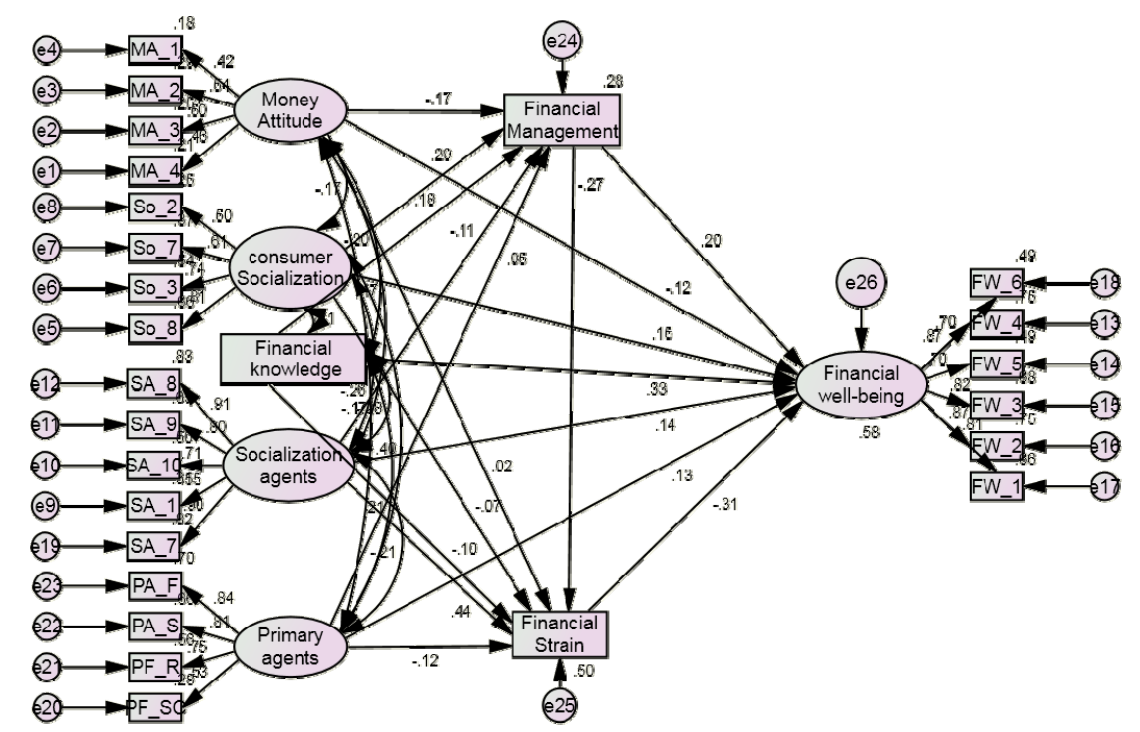

Figure 2. Predictors of financial wellbeing among female students

\section{Conclusions and Implications}

The findings of this research confirm the moderating effect of gender on financial wellbeing. The results reveal that males and females display different financial behaviour and perceive different levels of financial strain, financial knowledge, and financial attitude. Further, the effect of socialization agents and childhood consumer experiences on males and females are different, resulting in different levels of financial wellbeing. A comparison of the results reveal that financial management is the strongest predictor of financial wellbeing among male students while among females, financial knowledge and literacy are the main determinants. The results also reveal that with regard to financial strain, both males and females are affected by secondary socialization agents, which might constitute the main source of their experiencing financial strain. Assessment of financial management predictors reveal that male students are mostly affected by the negative effect of secondary socialization agents, while female students are affected by financial knowledge and the negative effect of financial attitude in conducting their finances.

The contribution of different factors in predicting financial wellbeing among male and female students reveals the importance of gender studies in financial issues. Furthermore, assessment of the findings reveal that secondary socialization agents (peers, media, magazines, the Internet and advertisements) have a negative effect on the financial wellbeing of male and female students alike. In other words, those who referred more to the media and advertisements for their monetary practices experience a higher level of financial strain and problems. The main interesting issue is the positive effect of the effect of secondary socialization agents on financial wellbeing, which also has a positive effect on financial strain and a negative effect on financial management, particularly among male students. The ambivalent effect of secondary socialization agents on financial 
management and financial wellbeing reveals that the peer group and media encourage students to enjoy their present life with no concern for the future. This effect may be related to the low level of students' financial skills and knowledge, which needs to be considered by family economics educators and practitioners involved in developmental programmes, particularly in the training of families and students. Since the effect of peer group and media is stronger during school days, schools could improve the quality of educational programmes and provide more practical subjects regarding financial literacy. Students then could not only develop financial skills but they could also learn how to apply this knowledge. As such, a professional curriculum must impart not only the essential knowledge and financial skills but also ways to improve students' stress management, self-efficacy, life skills, problem solving, and techniques for the intelligent and even appropriate use of financial assets. The findings of this study reveal that male students are more influenced by secondary socialization agents, requiring them to enhance their skills while in college life and improve their self-esteem and self-efficacy. Financial knowledge is the main determinant in enhancing female students' financial wellbeing while financial strain also has quite a high effect. Therefore, female students need to acquire more financial management skills, problem solving skills, and stress management skills. Since students will constitute the future labour force, there is a need to enhance their skills in planning for the future, such as career planning and financial planning.

\section{References}

Allen, M. W., Edwards, R., Hayhoe, C. R., \& Leach, L. (2007). Imagined interactions, family money management patterns and coalitions, and attitudes towards money and credit. Journal of Family and Economic Issues, 28, 3-22. http://dx.doi.org/10.1007/s10834-006-9048-1

Armstrong, C. J., \& Craven, M. J. (1993). Credit card use and payment practices among a sample of college students. Paper presented at the Proceedings of 6th Annual Conference of the Association for Financial Counseling and Planning Education.

Bakar, E. A., Masud, J., \& Jusoh, Z. M. (2006). Knowledge, Attitude and Perceptions of University Students towards Educational Loans in Malaysia. Journal of Family Economic Issues, 27, 692-701. http://dx.doi.org/ 10.1007/s10834-006-9035-6

Bentler, P. M., \& Chou, C. P. (1987). Practical issues in structural modelling. Sociological Methods \& Research, 16(1), 78-117. http://dx.doi.org/10.1177/0049124187016001004

Bhatti, N., Shar, A. H., Shaikh, F. M., \& Nazar, M. S. (2010). Women Participation in SMEs Business A Case Study of Sindh Province. International Journal of Business and Management, 5(10), 3. http://dx.doi.org/10. 5539/ijbm.v5n10p3

Borden, L. M., Lee, S.-A., Serido, J., \& Collins, D. (2008). Changing College Students' Financial Knowledge, Attitudes, and Behavior through Seminar Participation. Journal of Family Economy Issue, 29, 23-40. http://dx.doi.org/10.1007/s10834-007-9087-2

Braunstein, S., \& Welch, C. (2002, November). Financial Literacy; an Overview of Practice, Research and Policy. Federal Reserve Bulletin, 445-457.

Cantril, H. (1965). The pattern of human concerns. NJ, Rutgers U. P: New Brunswick.

Chen, H., \& Volpe, R. P. (1998). An analysis of personal financial literacy among college students. Financial Services Review, 7(2), 107-129. http://dx.doi.org/10.1016/S1057-0810(99)80006-7

Da, W. C. (2007). Public and private higher education institutions in Malaysia: Competing, complementary or crossbreeds as education providers. Kajian Malaysia, 25(1), 1-14.

Duck9Report. (2007). Statistics on college student Dropout Rates.

Falahati, L., \& Paim, L. (2011). Gender Differences in Financial Well-being. Financial Socialization and Financial Knowledge among College Students Life Science Journal, 8(3), 173-178.

Furnham, A. (1984). Many sides of the coin: The psychology of money usage. Personality and Individual Differences, 5(5), 501-509. http://dx.doi.org/10.1016/0191-8869(84)90025-4

Furnham, A. (1984). Many sides of the coin: The psychology of money usage. Personality and Individual Differences, 5, 96-103. http://dx.doi.org/10.1016/0191-8869(84)90025-4

Furnham, A. (1996). Attitudinal correlates and demographic predictors of monetary beliefs and behaviors. Journal of Organizational Behavior, 17, 373-388. http://dx.doi.org/10.1002/(SICI)1099-1379(199607)17: 4<375::AID-JOB767>3.0.CO;2-8

Goldscheider, F. K. (1990). The Aging of the Gender Revolution What Do We Know and What Do We Need to 
Know? Research on Aging, 12(4), 531-545. http://dx.doi.org/10.1177/0164027590124008

Gutter, M. S., Garrison, S., \& Copur, Z. (2010). Social Learning Opportunities and the Financial Behaviors of College Students. Family and Consumer Sciences Research Journal, 38(4), 387-404. http://dx.doi.org/10. $1111 /$ j.1552-3934.2010.00034.x

Hayhoe, C. R., Leach, L. J., Turner, P. R., Bruin, M. J., \& Lawrence, F. C. (2000). Differences in spending habits and credit card use of college students. The Journal of Consumer Affairs, 34(1), 113-133. http://dx.doi.org/ 10.1111/j.1745-6606.2000.tb00087.x

Hayhoe, C. R., Leach, L., \& Turner, P. R. (1999). Discriminating the number of credit cards held by college students using credit and money attitudes. Journal of Economic Psychology, 20, 643-656. http://dx.doi.org/ 10.1016/S0167-4870(99)00028-8

Hilgert, M. A., Hogarth, J. M., \& Beverly, S. G. (2003). Household financial management: The connection between knowledge and behavior. Federal Reserve Bulletin, 309-322.

Hira, T. K. (1997). Financial attitudes, beliefs and behaviors: Differences by age. Journal of Consumer Studies and Home Economics, 21, 271-290. http://dx.doi.org/10.1111/j.1470-6431.1997.tb00288.x

Hira, T. K., \& Mugenda, O. M. (1999). The relationships between self-worth and financial beliefs, behavior, and satisfaction. Journal of Family and Consumer Sciences Education, 91(4), 76-82.

Hira, T. K., \& Mugenda, O. M. (2000). Gender Differences in Financial Perceptions, Behaviors and Satisfaction. Journal of Financial Counselling and Planning, 13(2), 86-92.

Holub, T. (2002). Credit card usage and debt among college and university students. ERIC Document Reproduction Service No. ED466106.

Hung, A., Yoong, J., \& Brown, E. (2012). Empowering Women through Financial Awareness and Education. OECD Publishing. http://dx.doi.org/10.1787/5k9d5v6kh56g-en

Jariah, M., Husniyah, A. R., Laily, P., \& Britt, S. (2004). Financial Behavior and Problems among University Students: Need for Financial Education. Journal of Personal Finance, 3(1), 82-96.

John, D. R. (1999). Consumer Socialization of Children: A Retrospective Look at Twenty-Five Years of Research. Journal of Consumer Research, 26, 183-213. http://dx.doi.org/10.1086/209559

Kamaruddin, A. R., \& Mokhlis, S. (2003). Consumer socialization, social structural factors and decision-making styles: A case study of adolescents in Malaysia. International Journal of Consumer Studies, 27(2), 145-156. http://dx.doi.org/10.1046/j.1470-6431.2003.00297.x

Keith, V. M. (1993). Gender, financial strain, and psychological distress among older adults. Research on Aging, 15(2), 123-147. http://dx.doi.org/10.1177/0164027593152001

Lim, V. K. G., Teo, T. S. H., \& Loo, G. (2003). Sex, financial hardship and locus of control: An empirical study of attitudes towards money among Singaporean Chinese. Personality and Individual Differences, 34, 411-429. http://dx.doi.org/10.1016/S0191-8869(02)00063-6

Lown, J. M., \& Ju, I. S. (1992). A Model of Credit Use and Financial Satisfaction. Journal of Financial Counseling and Planning, 3, 105-125.

Lusardi, A., \& Mitchell, O. S. (2011). Financial literacy and planning: Implications for retirement wellbeing. National Bureau of Economic Research. http://dx.doi.org/10.3386/w17078

Mottola, G. R. (2013). In Our Best Interest: Women, Financial Literacy, and Credit Card Behavior. Numeracy, 6(2), 4. http://dx.doi.org/10.5038/1936-4660.6.2.4

NellieMae. (2002). Undergraduate Students and Credit Cards: An Analysis of Usage Rates and Trends.

NewComb, M., \& Rabow, J. (1999). Gender, Socilaization, and Money. Journal of Applied Social Psychology, 29(4), 852-869. http://dx.doi.org/10.1111/j.1559-1816.1999.tb02029.x

Norvilitis, J. M., \& Santa Maria, P. (2002). Credit card debt on college campuses: Causes, consequences, and solutions. College Student Journal, 36, 356-363.

Norvilitis, J. M., Merwin, M. M., Osberg, T. M., Roehling, P. V., Young, P., \& Kamas, M. M. (2006). Personality Factors, Money Attitudes, Financial Knowledge, and Credit-Card Debt in College Students. Journal of Applied Social Psychology, 36(6), 1395-1413. http://dx.doi.org/10.1111/j.0021-9029.2006.00065.x

Norvilitis, J. M., Szablicki, P. B., \& Wilson, S. D. (2003). Factors influencing levels of credit card debt in college 
students. Journal of Applied Social Psychology, 33, 935-947. http://dx.doi.org/10.1111/j.1559-1816.2003. tb01932.x

Owens, D., Lacey, K., Rawls, G., \& Holbert-Quince, J. A. (2010). First-Generation African American Male College Students: Implications for Career Counselors. The Career Development Quarterly, 58(4), 291-300. http://dx.doi.org/10.1002/j.2161-0045.2010.tb00179.x

Perry, V. G., \& Morris, M. D. (2005). Who Is in Control? The Role of Self-Perception, Knowledge, and Income in Explaining Consumer Financial Behavior. Journal of Consumer Affairs, 39(2), 299-313. http://dx.doi.org/ 10.1111/j.1745-6606.2005.00016.x

Roberts, J. A., \& Jones, E. (2001). Money attitudes, credit card use, and compulsive buying among American college students. Journal of Consumer Affairs, 35, 213-240. http://dx.doi.org/10.1111/j.1745-6606.2001. tb00111.x

Sabri, M. F., \& Falahati, L. (2012). Estimating a Model of Subjective Financial Well-Being among College Students. International Journal of Humanities and Social Science, 2(18), 191-199.

Sabri, M. F., \& Falahati, L. (2014). Toward a Framework of Financial Wellness Determinants: Investigating the Moderating Effect of Religion. Australian Journal of Basic and Applied Sciences, 8(9), 275-281.

Sabri, M. F., MacDonald, M., Hira, T. K., \& Masud, J. (2010). Childhood consumer experience and the financial literacy of college students in Malaysia. Family and Consumer Sciences Research Journal, 38(4), 455-467. http://dx.doi.org/10.1111/j.1552-3934.2010.00038.x

Shim, S., Xiao, J. J., Barber, B. L., \& Lyons, A. C. (2009). Pathways to life success: A conceptual model of financial well-being for young adults. Journal of Applied Developmental Psychology. http://dx.doi.org/10. 1016/j.appdev.2009.02.003

Tang, T. L. (1992). The meaning of money revisited. Journal of Organizational Behavior, 13, 197-202. http://dx.doi.org/10.1002/job.4030130209

Yamauchi, K. T., \& Templer, D. I. (1982). The development of a money attitude scale. Journal of Personality Assessment, 46, 522-528. http://dx.doi.org/10.1207/s15327752jpa4605_14

Yin-Fah, B. C., Masud, J., Hamid, T. A., \& Paim, L. (2010). Financial wellbeing of older peninsular Malaysians: A gender comparison. Asian Social Science, 6(3), 58. http://dx.doi.org/10.5539/ass.v6n3p58

\section{Copyrights}

Copyright for this article is retained by the author(s), with first publication rights granted to the journal.

This is an open-access article distributed under the terms and conditions of the Creative Commons Attribution license (http://creativecommons.org/licenses/by/3.0/). 